Final Technical Progress Report

\title{
Palladium/Copper Alloy Composite Membranes for High Temperature Hydrogen Separation from Coal-Derived Gas Streams
}

DOE Grant DE-FG26-99FT40585

\author{
Submitted by \\ J. Douglas Way \\ Chemical Engineering and Petroleum \\ Refining Department \\ Colorado School of Mines \\ Golden, CO 80401-1887
}

Office: (303) 273-3519

Telefax: (303) 273-3730

EMAIL: dway@mines.edu

Reporting Period: July 31, 1999 to December 31, 2002

Administrative Contact: Mary Mittag-Miller (303) 273-3411 


\section{DISCLAIMER}

This report was prepared as an account of work sponsored by an agency of the United States Government. Neither the United States Government nor any agency thereof, nor any of their employees, makes any warranty, express or implied, or assumes any legal liability or responsibility for the accuracy, completeness, or usefulness of any information, apparatus, product, or process disclosed, or represents that its use would not infringe privately owned rights. Reference herein to any specific commercial product, process, or service by trade name, trademark, manufacturer, or otherwise does not necessarily constitute or imply its endorsement, recommendation, or favoring by the United States Government or any agency thereof. The views and opinions of authors expressed herein do not necessarily state or reflect those of the United States Government or any agency thereof. 


\begin{abstract}
For hydrogen from coal gasification to be used economically, processing approaches that produce a high purity gas must be developed. Palladium and its alloys, nickel, platinum and the metals in Groups 3 to 5 of the Periodic Table are all permeable to hydrogen. Hydrogen permeable metal membranes made of palladium and its alloys are the most widely studied due to their high hydrogen permeability, chemical compatibility with many hydrocarbon containing gas streams, and infinite hydrogen selectivity. Our Pd composite membranes have demonstrated stable operation at $450{ }^{\circ} \mathrm{C}$ for over 70 days. Coal derived synthesis gas will contain up to $15000 \mathrm{ppm}$ $\mathrm{H}_{2} \mathrm{~S}$ as well as $\mathrm{CO}, \mathrm{CO}_{2}, \mathrm{~N}_{2}$ and other gases. Highly selectivity membranes are necessary to reduce the $\mathrm{H}_{2} \mathrm{~S}$ concentration to acceptable levels for solid oxide and other fuel cell systems. Pure Pd-membranes are poisoned by sulfur, and suffer from mechanical problems caused by thermal cycling and hydrogen embrittlement. Recent advances have shown that $\mathrm{Pd}-\mathrm{Cu}$ composite membranes are not susceptible to the mechanical, embrittlement, and poisoning problems that have prevented widespread industrial use of $\mathrm{Pd}$ for high temperature $\mathrm{H}_{2}$ separation. These membranes consist of a thin $(\leq 5 \square \mathrm{m})$ film of metal deposited on the inner surface of a porous metal or ceramic tube. With support from this DOE Grant, we have fabricated thin, high flux Pd$\mathrm{Cu}$ alloy composite membranes using a sequential electroless plating approach. Thin, $\mathrm{Pd}_{60} \mathrm{Cu}_{40}$ films exhibit a hydrogen flux more than ten times larger than commercial polymer membranes for $\mathrm{H}_{2}$ separation, resist poisoning by $\mathrm{H}_{2} \mathrm{~S}$ and other sulfur compounds typical of coal gas, and exceed the DOE Fossil Energy target hydrogen flux of $80 \mathrm{ml} / \mathrm{cm}^{2} \cdot \mathrm{min}=0.6 \mathrm{~mol} / \mathrm{m}^{2} \cdot \mathrm{s}$ for a feed pressure of 40 psig. Similar Pd-membranes have been operated at temperatures as high as $750^{\circ} \mathrm{C}$. We have developed practical electroless plating procedures for fabrication of thin $\mathrm{Pd}-\mathrm{Cu}$ composite membranes at any scale.
\end{abstract}




\section{TABLE OF CONTENTS}

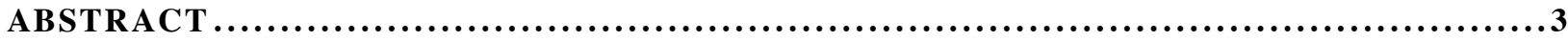

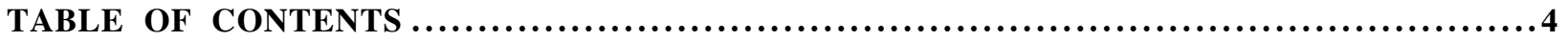

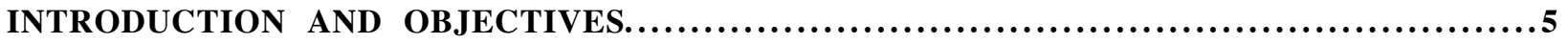

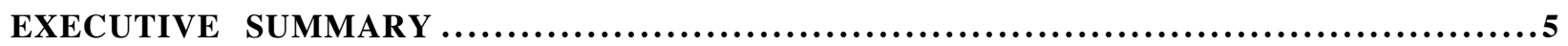

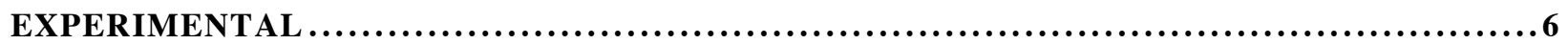

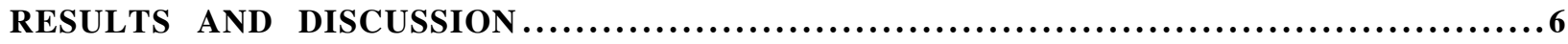

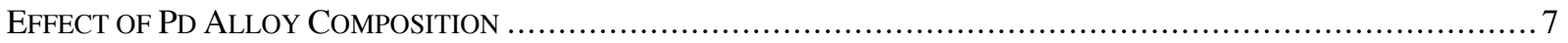

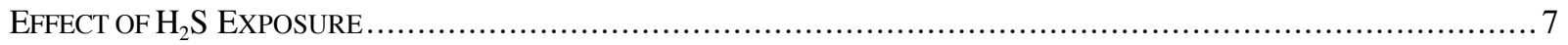

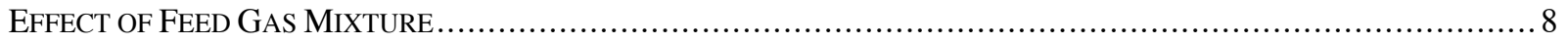

FABRICATION OF High SELECTIVITy Pd-CU MEMBRANE..................................................

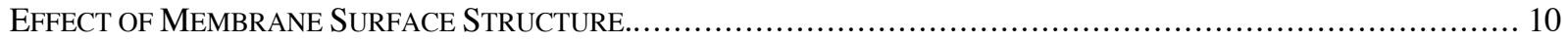

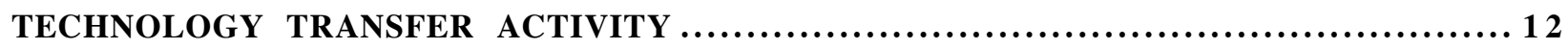

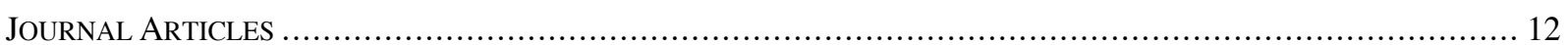

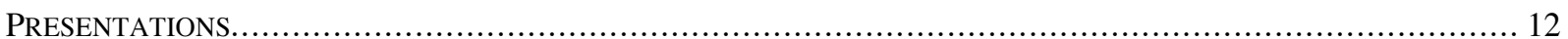

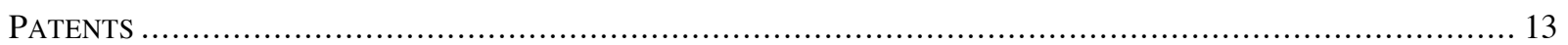

CONCLUSIONS..................................................................... 13

REFERENCES....................................................................... 13 


\section{INTRODUCTION AND OBJECTIVES}

Recent advances have shown that Pd-Cu composite membranes are not susceptible to the mechanical, embrittlement, and poisoning problems that have prevented widespread industrial use of $\mathrm{Pd}$ for high temperature $\mathrm{H}_{2}$ separation. These membranes consist of a thin $(\sim 1 \square \mathrm{m})$ film of metal deposited on the inner surface of a porous metal or ceramic tube. Based on preliminary results, thin $\mathrm{Pd}_{60} \mathrm{Cu}_{40}$ films are expected to exhibit hydrogen flux up to ten times larger than commercial polymer membranes for $\mathrm{H}_{2}$ separation, and resist poisoning by $\mathrm{H}_{2} \mathrm{~S}$ and other sulfur compounds typical of coal gas. Similar Pd-membranes have been operated at temperatures as high as $750^{\circ} \mathrm{C}$. The overall objective of the proposed project is to demonstrate the feasibility of using sequential electroless plating to fabricate $\mathrm{Pd}_{60} \mathrm{Cu}_{40}$ alloy membranes on porous supports for $\mathrm{H}_{2}$ separation. These following advantages of these membranes for processing of coal-derived gas were demonstrated:

- High $\mathrm{H}_{2}$ flux,

- Sulfur tolerant, even at very high total sulfur levels (1000 ppm),

- Operation at high temperatures,

- Resistance to embrittlement and degradation by thermal cycling.

The objectives of this research project were to provide a fundamental understanding of:

- Factors important in membrane fabrication.

- Optimization of membrane structure and composition.

- Effect of temperature, pressure, and gas composition on $\mathrm{H}_{2}$ flux and membrane selectivity.

- How this membrane technology can be integrated in coal gasification-fuel cell systems.

\section{EXECUTIVE SUMMARY}

For hydrogen from coal gasification to be used economically, processing approaches that produce a high purity gas must be developed. Palladium and its alloys, nickel, platinum and the metals in Groups 3 to 5 of the Periodic Table are all permeable to hydrogen. Hydrogen permeable metal membranes made of palladium and its alloys are the most widely studied due to their high hydrogen permeability, chemical compatibility with many hydrocarbon containing gas streams, and infinite hydrogen selectivity. Our Pd composite membranes have demonstrated stable operation at $450{ }^{\circ} \mathrm{C}$ for over 70 days. Coal derived synthesis gas will contain up to $15000 \mathrm{ppm}$ $\mathrm{H}_{2} \mathrm{~S}$ as well as $\mathrm{CO}, \mathrm{CO}_{2}, \mathrm{~N}_{2}$ and other gases. Highly selectivity membranes are necessary to reduce the $\mathrm{H}_{2} \mathrm{~S}$ concentration to acceptable levels for solid oxide and other fuel cell systems. Pure Pd-membranes suffer from mechanical problems caused by thermal cycling and hydrogen embrittlement. Recent advances have shown that $\mathrm{Pd}-\mathrm{Cu}$ composite membranes are not susceptible to the mechanical, embrittlement, and poisoning problems that have prevented widespread industrial use of $\mathrm{Pd}$ for high temperature $\mathrm{H}_{2}$ separation. These membranes consist of a thin $(\leq 5 \square \mathrm{m})$ film of metal deposited on the inner surface of a porous metal or ceramic tube.

With support from this DOE Grant, we have fabricated thin, high flux $\mathrm{Pd}-\mathrm{Cu}$ alloy composite membranes using a sequential electroless plating approach. Thin $\mathrm{Pd}_{60} \mathrm{Cu}_{40}$ films that exhibit a hydrogen flux more than ten times larger than commercial polymer membranes for $\mathrm{H}_{2}$ separation, resist poisoning by $\mathrm{H}_{2} \mathrm{~S}$ and other sulfur compounds typical of coal gas, and exceed the DOE Fossil Energy target hydrogen flux of $80 \mathrm{ml} / \mathrm{cm}^{2} \cdot \mathrm{min}=0.6 \mathrm{~mol} / \mathrm{m}^{2} \cdot \mathrm{s}$ for a feed pressure of $40 \mathrm{psig}$. Similar Pd-membranes have been operated at temperatures as high as $750^{\circ} \mathrm{C}$. We have developed practical electroless plating procedures for fabrication of thin $\mathrm{Pd}-\mathrm{Cu}$ composite membranes at any scale. 
We have shown that a 40 weight $\% \mathrm{Cu}$ binary alloy with $\mathrm{Pd}$ has the highest permeability, consistent with the literature on Pd alloy foils. Preliminary results have shown that although exposure to $\mathrm{H}_{2} \mathrm{~S}$ inhibits (reduces) the $\mathrm{H}_{2}$ flux, this effect is reversible. Permeation measurements with mixtures representative of synthesis gas show that the $\mathrm{H}_{2}$ flux is not inhibited by the presence of $\mathrm{CO}$. We have also made a membrane that exhibits very high ideal $\mathrm{H}_{2} / \mathrm{N}_{2}$ selectivity, $\geq$ 7000 .

\section{EXPERIMENTAL}

Composite alloy membranes were fabricated by sequential electroless plating of palladium and copper onto symmetric $0.2 \square \mathrm{m}$ cut-off $\square$-alumina tubes (CoorsTek GTC-998) and asymmetric 0.05 and $0.02 \square \mathrm{m}$ cut-off zirconia coated $\square$-alumina tubes (US Filter T1-70). A seeding procedure has to be used prior to the palladium plating in order to insure adhesion between the metallic film and the ceramic surface [1]. That step involves impregnation of the ceramic support using an organic Pd salt solution, followed by calcination and reduction in flowing hydrogen.

$\mathrm{Pd}$ and $\mathrm{Cu}$ electroless plating baths from the literature were then used in combination with osmotic pressure gradients to deposit films ranging from 1 to $25 \mu \mathrm{m}$ in thickness [2]. The osmotic pressure, generated by circulating concentrated sucrose solutions on the outside of the tubes, insured reduced porosity and promoted surface homogeneity and densification of the plated $\mathrm{Pd}$ film [3]. After sequential plating of $\mathrm{Pd}$ and $\mathrm{Cu}$ films, the membranes were annealed during hydrogen permeation tests at temperatures greater than $350{ }^{\circ} \mathrm{C}$ to produce homogeneous alloy membranes.

\section{RESULTS AND DISCUSSION}

Membranes with metal layer as thin as 1 micron were made routinely. Figure 1 shows an SEM image of a Pd-Cu composite membrane with a metal film roughly $1 \square \mathrm{m}$ thick. These membranes have very high fluxes as shown in Figure 2. However, it was found that the required metal film thickness to produce a leak-free membrane was a function of the plating time as well as being influenced by the support choice $[4,5]$. In the absence of structural defects in the support, the nominal pore size and smoothness of the top layer are the most important factors determining the minimal thickness to produce a leak free metal membrane $[2,5]$. Minimizing surface roughness allows thinner defect-free membranes to be made, but the adhesion, or penetration of the metal film in to the support, is decreased. Consequently, a balance must be found to minimize surface roughness while maintaining adequate adhesion of the $\mathrm{Pd}$ alloy film to the support.

The fluxes for these very thin Pd-Cu composite membranes exceed the DOE Fossil Energy program goal for hydrogen flux of $80 \mathrm{ml} / \mathrm{cm}^{2} \cdot \mathrm{min}=0.6 \mathrm{~mol} / \mathrm{m}^{2} \bullet \mathrm{s}$ for a feed pressure of $40 \mathrm{psig}$ [6]. As can be seen in Figure 2 below, the flux for a pure hydrogen feed pressure of 40 psig $=52$ psia is $\sim 0.8 \mathrm{~mol} / \mathrm{m}^{2} \bullet \mathrm{s}=107 \mathrm{ml} / \mathrm{cm}^{2} \bullet \min$ at the moderate temperature of $350{ }^{\circ} \mathrm{C}$. 


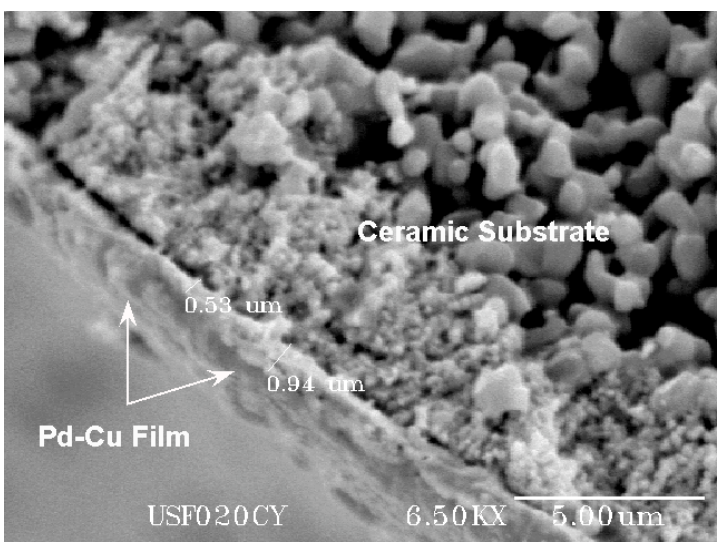

Figure 1. SEM picture of Pd-Cu composite membrane \#20, 90 mass \% Pd, on a 20 nm cut-off asymmetric ceramic filter. Scale bar is $5 \mu \mathrm{m}$.

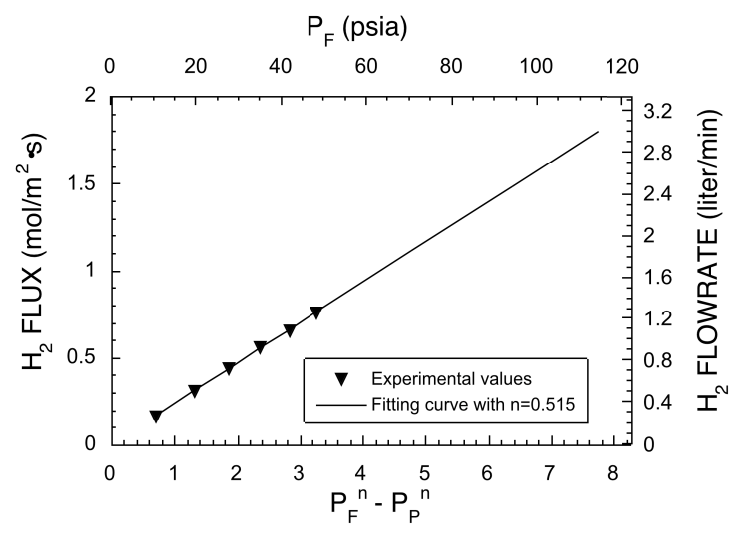

Figure 2. Influence of driving force on the pure gas $\mathrm{H}_{2}$ flux for a $1.5 \mu \mathrm{m}$ thick Pd-Cu membrane (\#25b) having 60 mass $\% \mathrm{Pd}$ at $350{ }^{\circ} \mathrm{C}$. $\mathrm{P}_{\mathrm{F}}$ is feed pressure.

\section{Effect of Pd Alloy Composition}

The composition of the $\mathrm{Pd}-\mathrm{Cu}$ alloy film has a strong influence on the $\mathrm{H}_{2}$ permeability. Figure 3 shows that the highest $\mathrm{H}_{2}$ permeability is observed for our composite membranes at a alloy composition of 60 mass \%. This is consistent with the patent literature for $\mathrm{Pd}-\mathrm{Cu}$ foil membranes [7]. Furthermore, the Pd inventory of this alloy and resulting cost is significantly less than the Pd-Ag alloy, for example, which has a maximum $\mathrm{H}_{2}$ permeability at 77 mass $\% \mathrm{Pd}$.

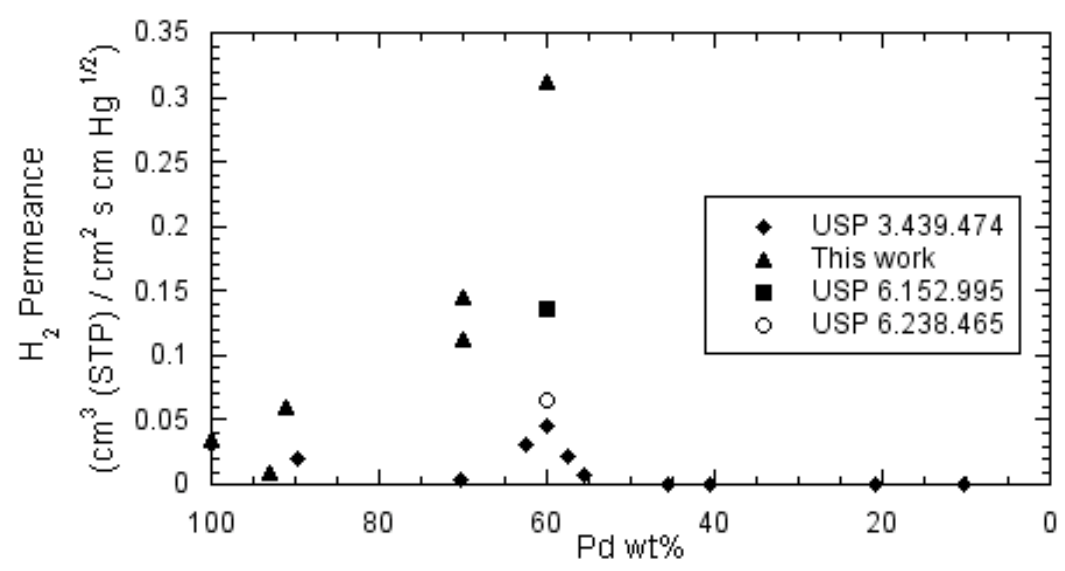

Figure 3. The influence of alloy composition on the pure $\mathrm{H}_{2}$ permeance for $\mathrm{Pd}-\mathrm{Cu}$ composite membranes at $350{ }^{\circ} \mathrm{C}$. The Figure compares our composite membranes to the performance of $\mathrm{Pd}-\mathrm{Cu}$ foil membranes from the patent literature [7-10]

\section{Effect of $\mathrm{H}_{2} \mathrm{~S}$ Exposure}

Figure 4 below shows the influence of $\mathrm{H}_{2} \mathrm{~S}$ exposure on the pure gas $\mathrm{H}_{2}$ flux for a Pd-Cu membrane. After annealing in He for 5 days, membrane USF-AK-20-9 was exposed to 100 ppm $\mathrm{H}_{2} \mathrm{~S}$ in an $8 \mathrm{hr}$ test. Before the $\mathrm{H}_{2} \mathrm{~S}$ exposure, the membrane had a steady state flux of 0.137 $\mathrm{mol} / \mathrm{m}^{2} \cdot \mathrm{s}$ and $\mathrm{H}_{2} / \mathrm{N}_{2}$ ideal selectivity of 23 at $450^{\circ} \mathrm{C}$ and $40 \mathrm{psig}$ feed pressure. The addition of $100 \mathrm{ppm} \mathrm{H}_{2} \mathrm{~S}$ to a mixture of $50 / 50 \mathrm{H}_{2} / \mathrm{N}_{2}$ balance for 8 hours decreased the $\mathrm{H}_{2}$ flux from 0.137 to $0.081 \mathrm{~mol} / \mathrm{s} / \mathrm{m}_{2}$ and ideal selectivity from 23 to 11 . Although after the first one hour of $\mathrm{H}_{2} \mathrm{~S}$ introduction, the flux through the membrane stabilizes, this indicates a $\sim 40 \%$ reduction in the 
hydrogen flux due to sulfur inhibition. However, it is anticipated that in the presence of steam, the inhibition of the $\mathrm{H}_{2}$ flux due to $\mathrm{H}_{2} \mathrm{~S}$ exposure will be less severe. Following the $\mathrm{H}_{2} \mathrm{~S}$ experiment, a $20 \% \mathrm{H}_{2} \mathrm{O} / \mathrm{H}_{2}$ mixture was used to sweep $\mathrm{H}_{2} \mathrm{~S}$ from the membrane for 2 hour. The $20 \% \mathrm{H}_{2} \mathrm{O} / \mathrm{H}_{2}$ sweep increased the $\mathrm{H}_{2}$ flux to $0.093 \mathrm{~mol} / \mathrm{m}^{2} \cdot \mathrm{s}$ and the ideal selectivity to 19 . Figure 1 presents these results in a graphic form. In addition, we also observed an increase in the ideal selectivity to 28 by purging the membrane with He overnight after the steam exposure. Air oxidations (described in detail in the Proposed Research section) will also reverse the effects of $\mathrm{H}_{2} \mathrm{~S}$ exposure.

These preliminary data suggest that our $\mathrm{Pd}-\mathrm{Cu}$ membranes, produced by sequential electroless plating, are not poisoned by exposure to $\mathrm{H}_{2} \mathrm{~S}$. Further research is needed to examine the effects of $\mathrm{Cu}$ composition in the $\mathrm{Pd}-\mathrm{Cu}$ alloy, the effect of $\mathrm{H}_{2} \mathrm{~S}$ concentration in the feed gas, and regeneration procedures such as air or steam oxidations.

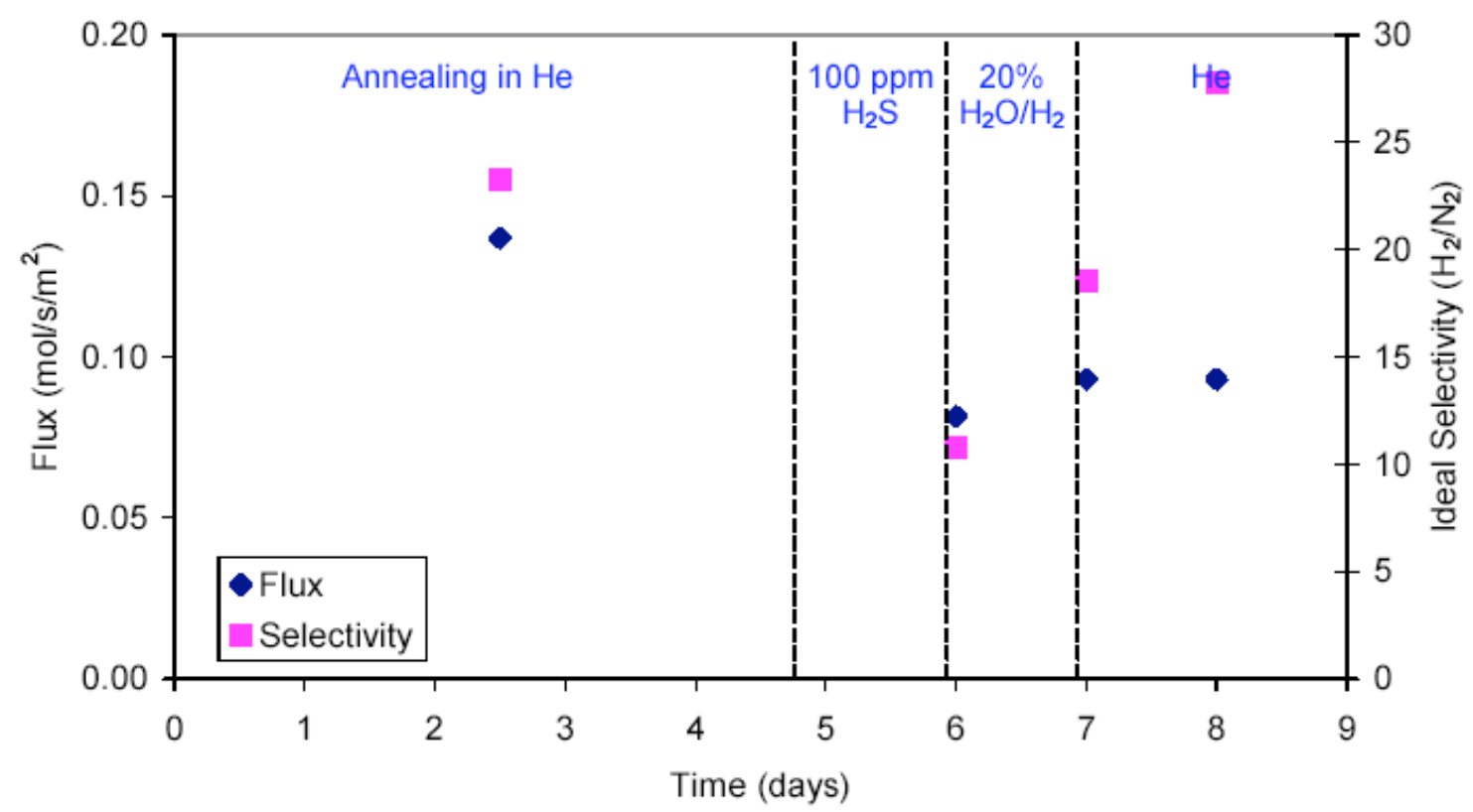

Figure 4. Effect of $\mathrm{H}_{2} \mathrm{~S}$ exposure on $\mathrm{H}_{2}$ single gas flux and $\mathrm{H}_{2} / \mathrm{N}_{2}$ ideal selectivity at 40 psig and $450^{\circ} \mathrm{C}$.

\section{Effect of Feed Gas Mixture}

Recently, we tested our Pd-Cu membrane performance in the presence of a model water gas shift (WGS) mixture gases having the following mixture concentration: $42 \% \mathrm{H}_{2}, 19 \% \mathrm{CO}_{2}, 4 \% \mathrm{CO}$ and $35 \% \mathrm{H}_{2} \mathrm{O}$, on volume basis. As shown in Figure 5, keeping the hydrogen partial pressure driving force constant, the hydrogen flux across the membrane for a 50 psig WGS feed mixture at $450{ }^{\circ} \mathrm{C}$, is approximately the same as that observed for a $42 \% \mathrm{H}_{2} / \mathrm{N}_{2}$ binary (shown in the first 45 minutes). 


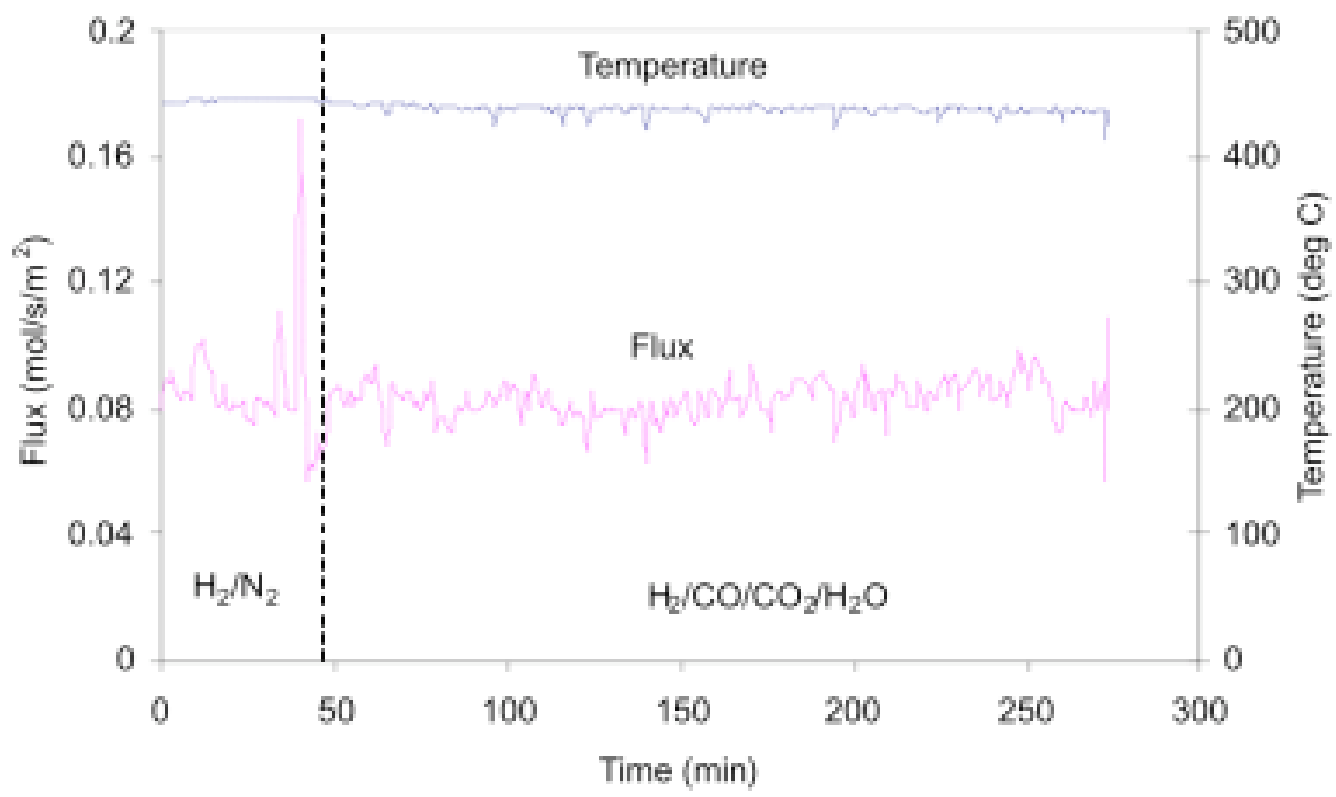

Figure 5. Flux versus time after introduction of WGS synthesis gas to membrane USF-AK-50-6 at 50 psi and $450^{\circ} \mathrm{C}$.

\section{Fabrication of High Selectivity Pd-Cu Membrane}

Figure 6 shows the complete data set for membrane \#28, a $\mathrm{PdCu}$ film $(8 \% \mathrm{Cu}$, balance $\mathrm{Pd})$ on a ceramic filter support. Until the "air purge" (controlled oxidation) treatment at 69 days, the $\mathrm{H}_{2} / \mathrm{N}_{2}$ selectivity of the membrane was at least 7000 , there was no measurable permeation of nitrogen. After reaching a steady-state flux at a temperature of $450{ }^{\circ} \mathrm{C}$, with a hydrogen feed pressure of $50 \mathrm{psig}$, the temperature was reduced to $400{ }^{\circ} \mathrm{C}$ and then $350{ }^{\circ} \mathrm{C}$ to compare with earlier data. As expected the $\mathrm{H}_{2}$ fluxes at these temperatures were higher than measured earlier in the test due to annealing of the $\mathrm{Pd}$ and $\mathrm{Cu}$ phases. The highest $\mathrm{H}_{2}$ flux of $0.35 \mathrm{~mole} / \mathrm{m}^{2} \bullet \mathrm{s}=0.78$ $\mathrm{cm}^{3}(\mathrm{STP}) / \mathrm{cm}^{2} \cdot \mathrm{s}$ was observed at $450{ }^{\circ} \mathrm{C}$ after 50 days of testing. 


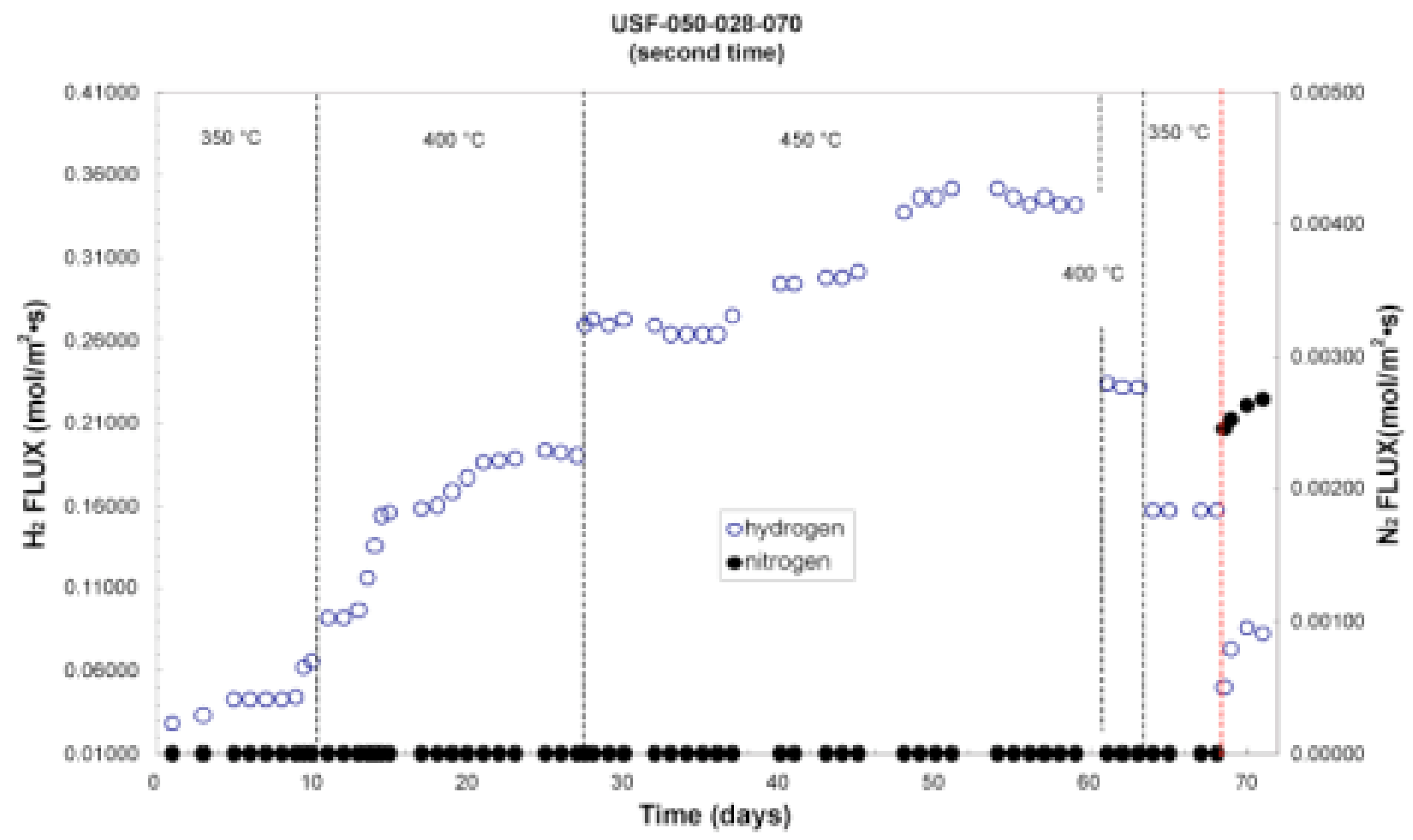

Figure 6. Complete data set for membrane \#28 for a feed pressure of $50 \mathrm{psig}$. Atmospheric pressure in Golden, $\mathrm{CO}$ is 12 psia. The black dotted lines denote change in temperature and the red dotted line represents an "air purge" treatment. Until the air purge treatment (red dotted line), the selectivity of the membrane was at least 7000, there was no measurable permeation of nitrogen. Immediately after the air purge the membrane developed a large inert gas leak and the selectivity dropped to approximately 30 .

\section{Effect of Membrane Surface Structure.}

We have observed an unexpected flux increase for our membranes following exposure to air at high temperature and subsequent reduction of the Pd oxide surface. For example, as shown in Figure 7, "air purge" treatments at 6, 8, and 13 days caused a sharp increase in the $\mathrm{H}_{2}$ flux. At 8 days, the $\mathrm{H}_{2}$ flux sharply increased to $0.7 \mathrm{~mol} / \mathrm{m}^{2} \cdot \mathrm{s}$ and then decreased to a new steady-state value of $0.5 \mathrm{~mol} / \mathrm{m}^{2} \cdot \mathrm{s}, 47 \%$ higher than the flux before the air purge treatment. The air purge was repeated for a third time at 13 days. 


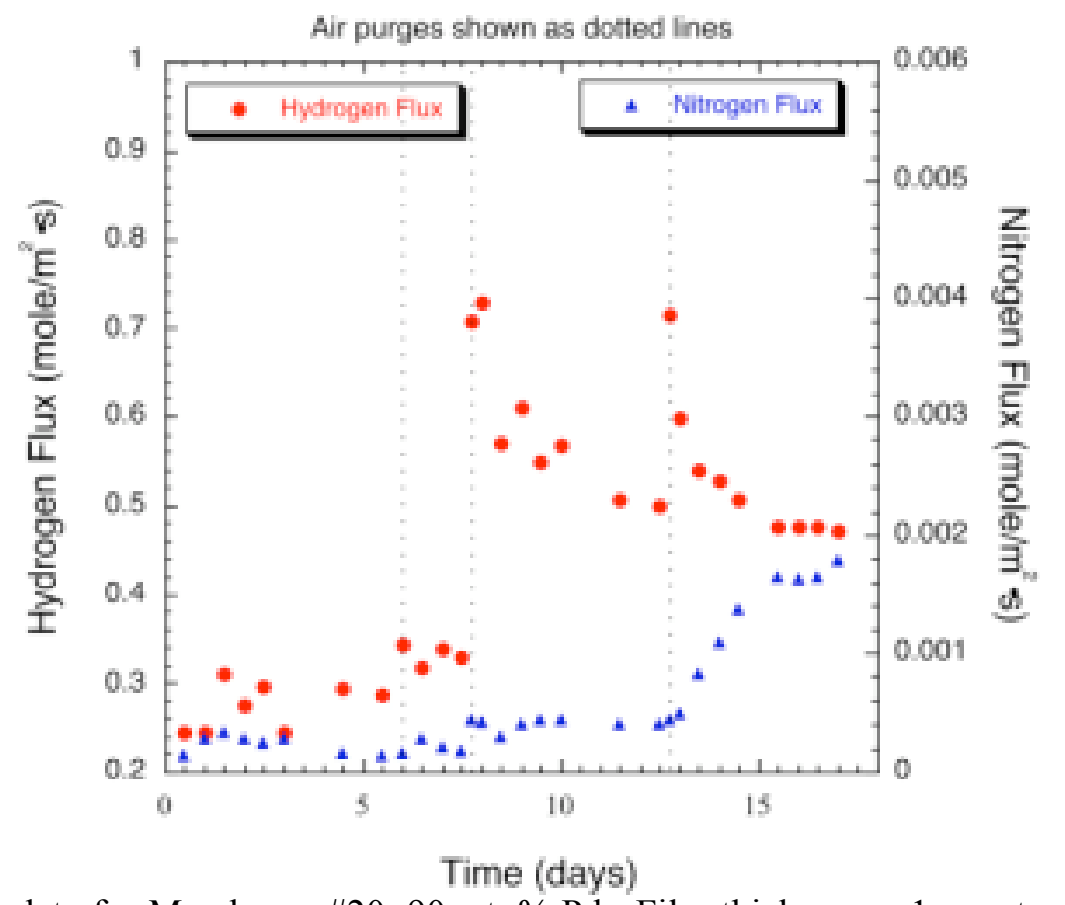

Figure 7. Flux data for Membrane \#20, 90 wt. \% Pd. Film thickness $\square 1 \mu \mathrm{m}$, temperature $=$ $350{ }^{\circ} \mathrm{C}$. The pressure differential for the permeation tests was $50 \mathrm{psig}$. Note the flux increases due to the "air purge" treatments, shown as a dotted lines.

The $\mathrm{H}_{2}$ flux increase is very similar, but this time the $\mathrm{N}_{2}$ flux increased dramatically. Further examination of the data show that the $\mathrm{N}_{2}$ did increase after each air purge treatment.

Figure 8 is a cartoon that presents our hypothesis for the mechanism of the air purge treatment. If the film rearranged due to the air purge, then leak paths could be formed between the conical structures formed by the larger volume of the oxide. The increased $\mathrm{H}_{2}$ flux could be due to increased surface area and/or unknown chemical effects. There is evidence in the nanotechnology literature to support this hypothesis. Figure 9 shows conical palladium oxide structures formed by oxidizing a Pd film on a single crystal oxide support at $900{ }^{\circ} \mathrm{C}[11]$. The height of these structures is approximately $1 \mu \mathrm{m}$, close to the thickness of our $\mathrm{Pd}-\mathrm{Cu}$ films. We
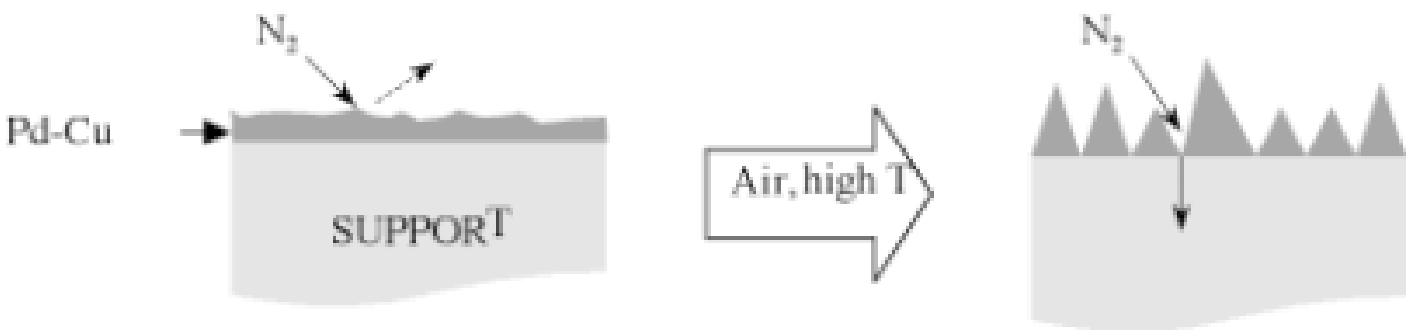

Figure 8. Cartoon showing our hypothesis for mechanism of air purge on thin Pd alloy membranes.

have shown (Figure 10) that a Pd film on a Si wafer formed by electroless deposition will show some similar conical structures upon oxidation but the temperatures are much higher than those used during air purge treatments. We intend to use AFM and XPS to further investigate this interesting and useful phenomenon in the future. AFM software can calculate the surface area of a sample, allowing us to plot flux versus surface area to see if the flux increases we observe are simply due to an increase in the number of sites for $\mathrm{H}_{2}$ dissociation. 


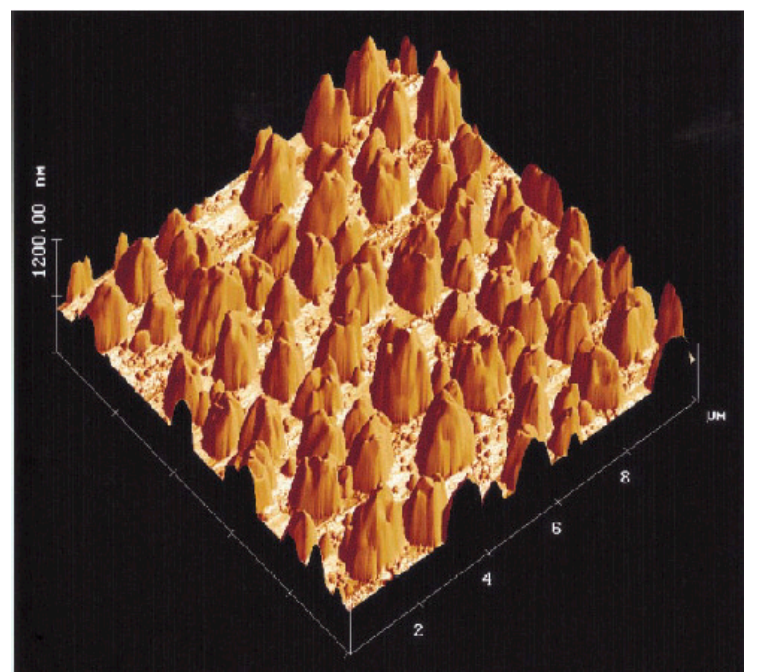

Figure 9. AFM image of Palladium oxide nano-structures formed by oxidation of a $\mathrm{Pd}$ film at $900{ }^{\circ} \mathrm{C}$ (Aggarwal et al., 2000).

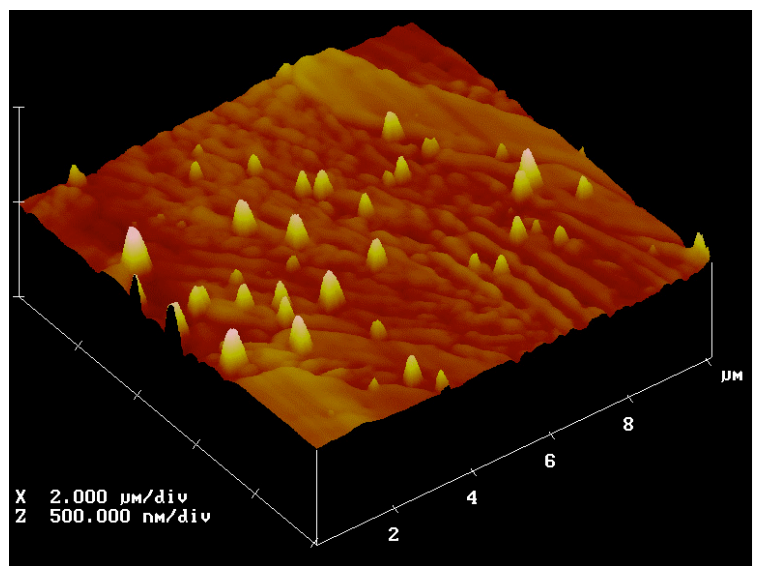

Figure 10. AFM image of the surface of an electrolessly deposited Pd film on a Si wafer oxidized at $900{ }^{\circ} \mathrm{C}$.

\section{TECHNOLOGY TRANSFER ACTIVITY}

The following journal articles, presentations, and patents were made at technical meetings related to this project:

\section{Journal Articles}

- Roa, F., Block, M. J., and J. D. Way, "The Influence of Alloy Composition on the $\mathrm{H}_{2}$ Flux of Pd-Cu Composite Membranes," Desalination, 147, 411-416(2002).

- Paglieri, S. N. and J. D. Way, "Innovations in Pd Membrane Research,” Separation and Purification Methods, 31(1), 1-169(2002).

- $\quad$ Roa, F. Way, J. D., McCormick, R. L. and S. N. Paglieri, "Preparation and Characterization of Pd-Cu Composite Membranes for Hydrogen Separation," The Chemical Engineering Journal, in press, 6/2002.

- Road, F. and J. D. Way, “The Pressure Dependence of the Hydrogen Flux of PalladiumCopper Composite Membranes, in preparation, 2003.

\section{Presentations}

- ICOM 99,6/99, Toronto, Canada, $\mathrm{Pd} / \mathrm{Cu}$ Composite Membranes for $\mathrm{H}_{2}$ Separations (talk given by Steve Paglieri)

- DOE-UCR Contractor's Meeting, Pittsburgh, PA 6/00, Pd-Cu Alloy Composite Membranes for Hydrogen Separations

- Los Alamos National Laboratory, Los Alamos, NM, 12/00, New Materials for Gas and Liquid Separations

- ACS National Meeting, San Diego, CA, 4/01, Micron Scale Pd-Cu Alloy Composite Membranes for Hydrogen Separations 
- DOE-UCR Contractor's Meeting, Pittsburgh, PA 6/01, Pd-Cu Alloy Composite Membranes for Hydrogen Separations

- The North American Catalysis Society annual meeting, Toronto, Canada, 6/01, Scale Pd-Cu Alloy Composite Membranes for Hydrogen Separations and Membrane Reactors

- Idaho National Engineering and Environmental Laboratory, Idaho Falls, ID, 7/01, New Materials for Gas and Liquid Separations

- ICOM 02, Toulouse, France, 6/02, The Influence of Alloy Composition on the $\mathrm{H}_{2}$ Flux of $\mathrm{Pd}-\mathrm{Cu}$ Composite Membranes (talk given by Fernando Roa)

\section{Patents}

- Way, J. D., Roa, F. and S. N. Paglieri, "Process for Preparing Palladium Alloy Composite Membranes for Use in Hydrogen Separation, Palladium Alloy Composite Membranes and Products Incorporating or Made From the Membranes," U. S. Patent Application, April 3, 2002.

\section{CONCLUSIONS}

Our previous results have shown that we can fabricate thin, high flux $\mathrm{Pd}-\mathrm{Cu}$ alloy composite membranes using a sequential electroless plating approach. We have shown that a 40 weight \% $\mathrm{Cu}$ binary alloy with $\mathrm{Pd}$ has the highest permeability, consistent with the literature on Pd alloy foils. As shown in Figure 2, a $1.5 \mu \mathrm{m}$ thick $\mathrm{Pd}_{60} \mathrm{Cu}_{40}$ membrane meets the DOE hydrogen flux target. Preliminary results have shown that although exposure to $\mathrm{H}_{2} \mathrm{~S}$ inhibits (reduces) the $\mathrm{H}_{2}$ flux, this effect is reversible. Permeation measurements with mixtures representative of synthesis gas show that the $\mathrm{H}_{2}$ flux is not inhibited by the presence of $\mathrm{CO}$. We have also made a membrane that exhibits very high ideal $\mathrm{H}_{2} / \mathrm{N}_{2}$ selectivity, $\geq 7000$.

\section{REFERENCES}

1. Paglieri, S.N., K.Y. Foo, J.D. Way, J.P. Collins, and D.L. Harper-Nixon, A new preparation technique for Pd/alumina membranes with enhanced high temperature stability. Ind. Eng. Chem. Res., 1999. 38(5): p. 1925-36.

2. Roa, F., M.J. Block, and J.D. Way, The influence of alloy composition on the $\mathrm{H}_{2}$ flux of composite Pd-Cu membranes. Desalination, 2002. 147: p. 411-416.

3. Yeung, K.L., J.M. Sebastian, and A. Varma, Novel preparation of Pd/Vycor composite membranes. Catal. Today, 1995. 25: p. 231-236.

4. Jayaraman, V., Y.S. Lin, M. Pakala, and R.Y. Lin, Fabrication of ultrathin metallic membranes on ceramic supports by sputter deposition. J. Membr. Sci., 1995. 99: p. 89-100.

5. Xomeritakis, G. and Y.S. Lin, Fabrication of thin metallic membranes by MOCVD and sputtering. J. Membr. Sci., 1997. 133(2): p. 217-30.

6. Bose, A.C. Inorganic Membranes; A New Paradigm for Reaction, Separation, and Carbon Dioxide Remediation. in 6th International Conference on Inorganic Membranes. 2000. Montpelier, France.

7. McKinley, D.L., Method for hydrogen separation and purification, U.S. Patent 3,439,474, 1969. 
8. McKinley, D.L., Metal alloy for hydrogen separation and purification, U.S. Patent 3,350,845, 1967.

9. Juda, W., C.W. Krueger, and R.T. Bombard, Method of fabricating thinned free-standing metallic hydrogen-selective palladium-bearing membranes and novel pin-hole-free membranes formed thereby, Patent U.S. 6,103,028, 2000.

10. Edlund, D.J., Hydrogen Permeable Metal Membrane and Method for Producing the Same, U. S. Patent 6,152,995, 2000.

11. Aggarwal, S., A.P. Monga, S.R. Perusse, R. Ramesh, V. Ballarotto, E.D. Williams, B.R. Chalamala, Y. Wei, and R.H. Reuss, Spontaneous Ordering of Oxide Nanostructures. Science, 2000. 287: p. 2235-7. 